\title{
U-Pb dating of middle Eocene-Pliocene multiple tectonic pulses in the Alpine foreland
}

\author{
Luca Smeraglia ${ }^{1,2, a}$, Nathan Looser ${ }^{3}$, Olivier Fabbri ${ }^{2}$, Flavien Choulet $^{2}$, Marcel Guillong ${ }^{3}$, and \\ Stefano M. Bernasconi ${ }^{3}$ \\ ${ }^{1}$ National Research Council, IGAG, Rome, Italy \\ ${ }^{2}$ Chrono-Environnement, UMR 6249, Université de Bourgogne-Franche Comté, 25000 Besançon, France \\ ${ }^{3}$ Geological Institute, ETH Zürich, Sonneggstrasse 5, 8092 Zurich, Switzerland

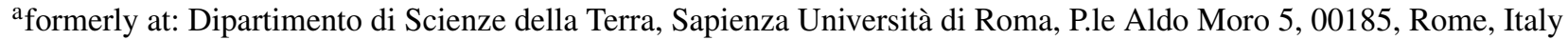

Correspondence: Nathan Looser (nathan.looser@erdw.ethz.ch)

Received: 7 January 2021 - Discussion started: 4 February 2021

Revised: 10 September 2021 - Accepted: 16 September 2021 - Published: 9 November 2021

\begin{abstract}
Foreland fold-and-thrust belts (FTBs) record longlived tectono-sedimentary activity, from passive margin sedimentation, flexuring, and further evolution into wedge accretion ahead of an advancing orogen. Therefore, dating fault activity is fundamental for plate movement reconstruction, resource exploration, and earthquake hazard assessment. Here, we report $\mathrm{U}-\mathrm{Pb}$ ages of syn-tectonic calcite mineralizations from four thrusts and three tear faults sampled at the regional scale across the Jura fold-and-thrust belt in the northwestern Alpine foreland (eastern France). Three regional tectonic phases are recognized in the middle Eocene-Pliocene interval: (1) pre-orogenic faulting at $48.4 \pm 1.5$ and $44.7 \pm 2.6 \mathrm{Ma}$ associated with the far-field effect of the Alpine or Pyrenean compression, (2) syn-orogenic thrusting at $11.4 \pm 1.1,10.6 \pm 0.5,9.7 \pm 1.4,9.6 \pm 0.3$, and $7.5 \pm 1.1 \mathrm{Ma}$ associated with the formation of the Jura foldand-thrust belt with possible in-sequence thrust propagation, and (3) syn-orogenic tear faulting at $10.5 \pm 0.4,9.1 \pm 6.5$, $5.7 \pm 4.7$, and at $4.8 \pm 1.7 \mathrm{Ma}$ including the reactivation of a pre-orogenic fault at $3.9 \pm 2.9 \mathrm{Ma}$. Previously unknown faulting events at $48.4 \pm 1.5$ and $44.7 \pm 2.6 \mathrm{Ma}$ predate the reported late Eocene age for tectonic activity onset in the Alpine foreland by $\sim 10 \mathrm{Myr}$. In addition, we date the previously inferred reactivation of pre-orogenic strike-slip faults as tear faults during Jura imbrication. The $\mathrm{U}-\mathrm{Pb}$ ages document a minimal time frame for the evolution of the Jura FTB wedge by possible in-sequence thrust imbrication above the low-friction basal decollement consisting of evaporites.
\end{abstract}

\section{Introduction}

Foreland fold-and-thrust belts develop at the external edges of orogens and are characterized by a multiphase tectonosedimentary history including pre-orogenic sedimentation, uplift at the peripheral bulge of the advancing orogen, progressively accelerating subsidence followed by syn-orogenic sedimentation, and accretion of the sedimentary cover into the fold-and-thrust belt (Lacombe et al., 2007). Unravelling the timing of these tectonic events is fundamental for plate kinematic modelling, natural resource exploration, paleoseismicity, and topography evolution studies (Vergés et al., 1992; Craig and Warvakai, 2009). However, deciphering the different tectonic phases is complicated due to the overprinting of inherited structures by progressively younger tectonic events.

This issue is addressed by dating syn-tectonic sediments and, more recently, better constrained through the dating of fault activity with $\mathrm{K}-\mathrm{Ar},{ }^{40} \mathrm{Ar} /{ }^{39} \mathrm{Ar}$, and $\mathrm{U}-\mathrm{Pb}$ and $\mathrm{U}-\mathrm{Th}$ methods (Van der Pluijm et al., 2001; Vrolijk et al., 2018). In particular, calcite $\mathrm{U}-\mathrm{Pb}$ and $\mathrm{U}-\mathrm{Th}$ geochronology (Roberts et al., 2020) is the unique method for dating syn-tectonic calcite mineralizations. This technique has been applied for dating single faults in extensional, strike-slip, and compressional settings (Goodfellow et al., 2017; Nuriel et al., 2017; Hansman et al., 2018; Smeraglia et al., 2019; Carminati et al., 2020). So far, the dating of multiple faults at the regional scale across a foreland fold-and-thrust belt remains rare (Beaudoin et al., 2018; Looser et al., 2021). 


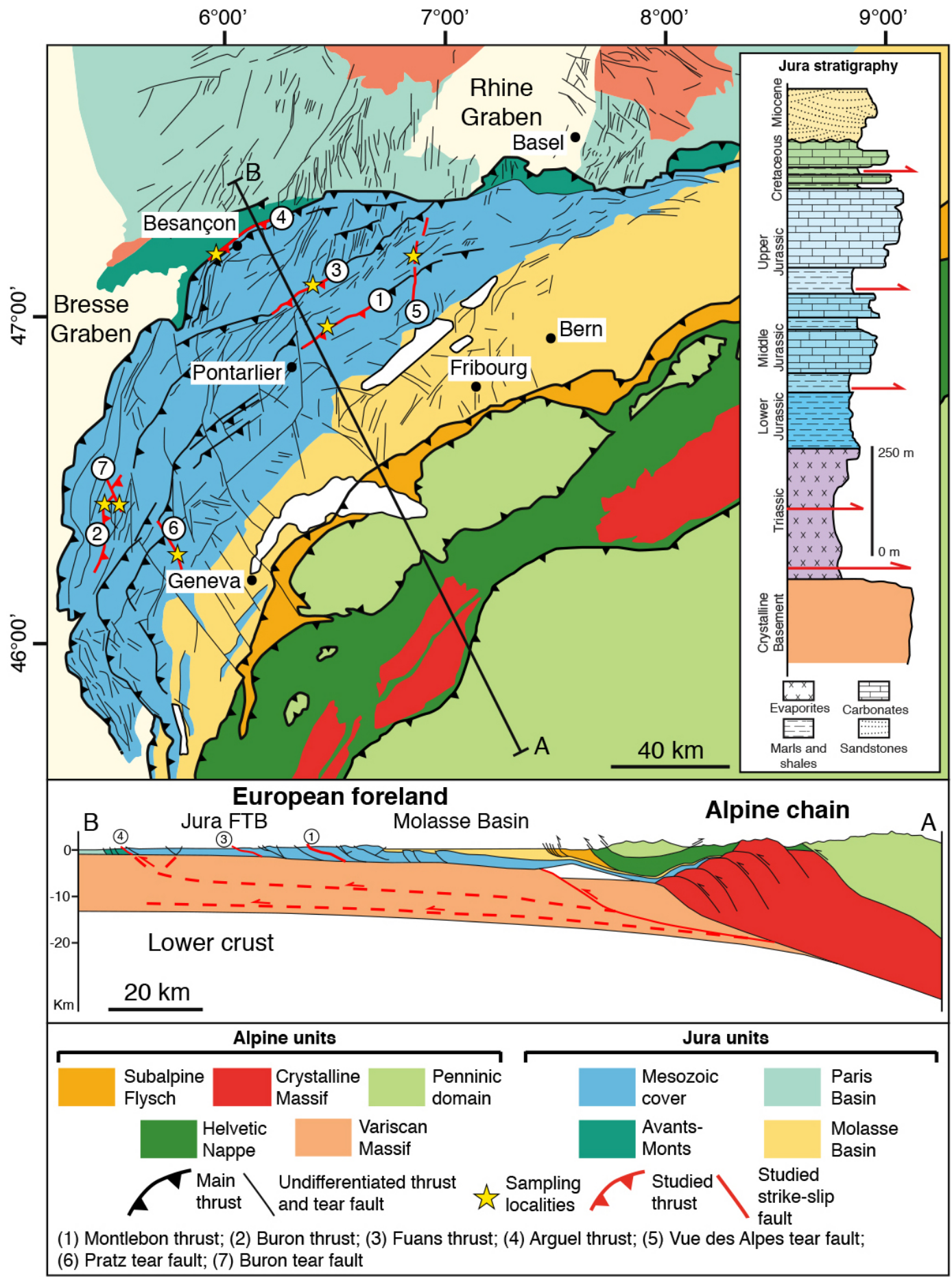

Figure 1. Geological map of the northwestern Alpine foreland and surrounding areas and stratigraphic column of the main lithological units of the Jura area. Map modified from Rime et al. (2019); cross section modified from Von Hagke et al. (2014).

In this study, we dated syn-tectonic calcite mineralizations from four thrusts and three tear faults sampled across the Jura fold-and-thrust belt at the regional scale (Jura FTB, eastern France, Fig. 1) by laser ablation inductively coupled plasma mass spectrometry (LA-ICP-MS) U-Pb dating. We reconstructed three tectonic phases having occurred in the middle Eocene-Pliocene period, documenting the long-lived polyphase tectonic history of the northwestern Alpine foreland system along the convergent boundary between the European and African plates. 


\section{Tectonic setting}

Located in the foreland of the Western Alps, the Jura FTB was formed by the ongoing continental collision of the European plate with the African plate (Sommaruga, 1997; Mosar, 1999; Lacombe and Mouthereau, 2002; Affolter and Gratier 2004; Bellahsen et al., 2014) (Fig. 1). Shortening affected the Triassic-late Miocene sedimentary succession deposited on the European passive margin above the Hercynian crystalline basement and caused brittle-ductile deformation at different crustal levels (Fig. 1) (Philippe et al., 1996; Homberg et al., 2002; Ustaszewski and Schmid, 2006). The sedimentary succession starts with Triassic shales and evaporites overlain by Jurassic-Cretaceous shales, marls, and limestones (Fig. 1) (Sommaruga et al., 2017). Following a Late CretaceousEocene regional unconformity, Oligocene-Miocene shallow marine to continental clastic deposits of the Molasse Basin were deposited above Cretaceous limestones (Fig. 1).

The post-Mesozoic tectonic history of the Jura area is assumed to have started in the middle Eocene with $\mathrm{N}-\mathrm{S}$ shortening related to the far-field effect of the "Pyrenean orogeny" generating strike-slip faults (Bergerat, 1987). However, no absolute ages of this tectonic phase are available. Based on structural analyses and calcite $\mathrm{U}-\mathrm{Pb}$ ages, three phases of normal faulting during the late Eocene, Oligocene, and Miocene in the distal parts of the Molasse Basin in northern Switzerland and in the Jura area have been documented (Lacombe et al., 1993; Homberg et al., 2002; Mazurek et al., 2018; Radaideh and Mosar, 2021). Normal faulting during the late Eocene-Oligocene is associated with crustal extension due to the opening of the Rhine Graben (Lacombe et al., 1993; Homberg et al., 2002; Mazurek et al., 2018; Radaideh and Mosar, 2021) or to the coeval onset of Alpine collision (Merle and Michon, 2001), while normal faulting during the middle Miocene has been related to crustal tilting associated with uplift of the Black Forest Highlands and subsidence of the northern part of the Molasse Basin (Mazurek et al., 2018).

Biostratigraphic ages of syn-orogenic deposits, geomorphological observations, interpretation of seismic reflection profiles, and syn-tectonic calcite $\mathrm{U}-\mathrm{Pb}$ ages of fault activity in the eastern tip of Jura FTB indicate that orogenic shortening started $\sim 14.5 \mathrm{Myr}$ ago (Langhian times) at the latest (Looser et al., 2021, and references therein) and is still active (Mosar, 1999; Becker, 2000; Lacombe and Mouthereau, 2002; Madritsch et al., 2008). Shortening was accommodated by $\mathrm{N}$ - to NE-verging and NE-SW-striking thrusts and by NW-SE- to N-S-trending sinistral tear faults (Sommaruga, 1997) (Fig. 1). The main decollement level of the thrust system developed along Triassic evaporites (Jordan, 1992; Pfiffner, 2014; Gruber, 2017; Sommaruga et al., 2017). Therefore, there is a common agreement in considering the Jura FTB mainly as the product of thin-skinned tectonics (Sommaruga, 1997). However, thick-skinned tectonics occurred in the late stage of deformation, mostly in the external part of the chain (Lacombe and Mouthereau, 2002; Us- taszewski and Schmid, 2006, 2007; Madritsch et al., 2008; Lacombe and Bellahsen, 2016).

Field cross-cutting relationships and U-Pb ages of syntectonic calcite mineralizations show that tear faults were synchronously active during thrusting and folding (Sommaruga, 1997; Looser et al., 2021) and their movement continued after thrusting. In fact, in some cases, tear faults are still seismogenic (Thouvenot et al., 1998). Several authors suggest that pre-orogenic strike-slip and normal faults were reactivated in the early Pliocene as tear and transpressional faults, respectively (Madritsch et al., 2008; Homberg et al., 1997; Ustaszewski and Schmid, 2006). Overall, direct dating of this fault reactivation is so far not available.

\section{Methods}

The following methods were used: (1) field structural analyses and vein and slickenfibre sampling from four major thrusts (from SE to NW: Montlebon, Buron, Fuans, and Arguel thrusts) and three tear faults (Vue des Alpes, Pratz, and Buron) moving from the internal (most deformed) to the external (less deformed) parts of the Jura FTB (Fig. 1). In particular, we measured the orientation of sampled veins and the rake of sampled slickenfibres in order to combine U$\mathrm{Pb}$ ages with structural measurements; (2) microstructural analyses with optical and cathodoluminescence (CL) microscopy to unravel different phases of calcite precipitation; (3) calcite U-Pb LA-ICP-MS dating on veins and slickenfibres to date fault activity. In most cases, the U-Pb analyses were performed on calcite crystals showing a homogenous colour or undisturbed growth zoning under cathodoluminescence light, indicating no open-system alteration after calcite precipitation by late fluid infiltration and/or recrystallization (Figs. S1-S3). Analytical details are described in the Supplement.

\section{Results}

\subsection{Structural and microstructural observations}

The Montlebon, Buron, Fuans, and Arguel thrusts are NNESSW- to SW-NE-striking and N- to NW-verging thrusts (Madritsch et al., 2008; Rime et al., 2019; Smeraglia et al., 2020) (Fig. 2a-d). More precisely, the Montlebon thrust is characterized by E- to ESE-dipping (30-90 $)$ thrust planes with slickenfibres showing left-lateral transpressional movements with $\mathrm{N}$ to NNW tectonic transport directions (Fig. 2a). The Buron thrust is characterized by E- to SE-dipping (20$30^{\circ}$ ) thrust planes with slickenfibres showing left-lateral transpressional movements with NW tectonic transport directions (Fig. 2b). The Fuans thrust is characterized by E- to SE-dipping $\left(20-40^{\circ}\right)$ thrust planes with slickenfibres showing left-lateral transpressional movements with NNW to NW tectonic transport directions (Fig. 2c). The Arguel thrust is 
characterized by S-dipping $\left(10-30^{\circ}\right)$ thrust planes with slickenfibres showing right-lateral transpressional movements with NNW tectonic transport directions (Fig. 2d).

The subvertical Vue des Alpes, Pratz, and Buron tear faults show sinistral strike-slip displacements (Sommaruga, 1997) (Fig. 2de-g). More precisely, the Vue des Alpes strikeslip fault is characterized by NE-SW-striking subvertical fault planes with slickenfibres showing sinistral movements and associated NW-SE-striking subvertical fault planes with slickenfibres showing dextral movements (Fig. 2e). Both the Pratz and Buron strike-slip faults are characterized by NESW-striking subvertical fault planes with slickenfibres showing sinistral movements (Fig. 2f-g).

Thrusts and strike-slip faults cut through Middle-Upper Jurassic and Lower Cretaceous limestones. The fault core zones are characterized by foliated fault rocks cut by sharp fault planes (Fig. 3a-d). Breccia lenses are developed in the Buron thrust core (Fig. 4d). Calcite mineralizations in extensional veins (Buron, Arguel, Montlebon, Vue des Alpes, and Pratz) and in slickenfibres (Fuans, Vue des Alpes, and Pratz) were sampled.

Extensional veins occur in limestone fragments of foliated fault rocks (Fig. 3e, g) and in clasts from breccias (Figs. 3f and $4 \mathrm{~g}$ ). In limestone fragments of foliated fault rocks, extensional veins are oriented perpendicularly to stylolites (Fig. 3e, g), which occur along S and C planes. Extensional veins in clasts from breccias show a crackle-like texture and mutually cross-cutting relationships (Fig. 3f). Extensional veins are filled by blocky to elongated-blocky calcite crystals, which show syntaxial growth (Figs. 3i-k, 4g, S1a-d, S2a, b, g, h, S3a-h).

The fault planes are coated by slickenfibres (Figs. 3d, h and $4 \mathrm{e}, \mathrm{f})$. At the microscale, slickenfibres occur in dilational jogs along shear planes (Fig. $3 \mathrm{~h}$ ) and are filled by fibrous calcite crystals bounded by sharp shear planes (Figs. 3j, 4i, S1e-h, and S2c-f) and/or by blocky calcite crystals (Figs. 31 and $4 \mathrm{~h}$ ). Fibrous crystals are oriented parallel to shear planes.

Most of the studied veins and slickenfibres show homogenous cathodoluminescence colours, ranging from bright to dull red, and/or cathodoluminescence zoning on the same crystal (Figs. 3i-1, 4g-i, S1a, c, e, g, S2a, c, e, g, and S3a, c, e, g). In places, slickenfibres and extensional veins are cross-cut by extensional veins showing black to dull red luminescence colours (Figs. S1e-h, S2c-f, and S3a, b, g, h).

\subsection{U-Pb dating}

A total of 12 reliable lower intercept ages (Figs. 5 and 6) out of 19 analyses (rejected age data are presented in Fig. S4) are reported with uncertainties at $2 \sigma$ absolute including counting statistics uncertainties, uncertainty of the primary reference material, and inter-analysis variations (Guillong et al., 2020). The U-Pb ages indicate different phases of tectonic activity and related calcite precipitation in the middle Eocene to
Pliocene period and also multiple precipitation ages along the same fault (Supplement Table S1).

An extensional vein from the Montlebon thrust shows a Serravallian age of $11.4 \pm 1.1 \mathrm{Ma}$ (Fig. 5a). An extensional vein from the Buron thrust shows a Tortonian age of $10.6 \pm$ $0.5 \mathrm{Ma}$ (Fig. 5b). Two slickenfibres from the Fuans thrust yield Tortonian ages, which are indistinguishable from each other, of 9.7 $\pm 1.4 \mathrm{Ma}$ and $9.6 \pm 0.3 \mathrm{Ma}$, respectively (Fig. 5c, d). An extensional vein from the Arguel thrust shows a Tortonian-Messinian age of $7.5 \pm 1.1 \mathrm{Ma}$ (Fig. 5e). Along the Vue des Alpes strike-slip fault, two slickenfibres yield Ypresian-Lutetian ages of $44.7 \pm 2.6 \mathrm{Ma}$ and $48.4 \pm 1.5 \mathrm{Ma}$ (Fig. 6a, b), while an extensional vein shows a Pliocene age of $3.9 \pm 2.9 \mathrm{Ma}$ (Fig. 6c). An extensional vein from the Buron strike-slip fault shows a Messinian age of 5.7 $\pm 4.7 \mathrm{Ma}$ (Fig. 6d). One slickenfibre and one extensional vein from the Pratz strike-slip fault show Tortonian-Messinian ages of $10.5 \pm 0.4 \mathrm{Ma}$ and $9.1 \pm 6.5 \mathrm{Ma}$ (Fig. $6 \mathrm{f}-\mathrm{g}$ ), while one slickenfibre shows a younger age of $4.8 \pm 1.7 \mathrm{Ma}$ (Fig. 6e). Because of the common-lead-rich ${ }^{207} \mathrm{~Pb} /{ }^{206} \mathrm{~Pb}$ compositions, the U$\mathrm{Pb}$ ages of the samples DA2, BUS1, PR1-A, and PR2-2 from the strike-slip faults have larger uncertainties than those from the thrusts.

\section{Discussion and conclusions}

Slickenfibres on sharp fault planes are clear evidence of tectonic slip along faults (Figs. 3j-1, 4i, S1e-h, and S2c, f). In particular, blocky and fibrous crystals indicate fast and slow vein opening rates, respectively, associated with fault slip. Within slickenfibres, calcite crystals precipitated during syn-slip to early post-slip fluid influx in newly formed dilational sites formed along undulated and sharp shear planes (Gratier and Gamond, 1990; Urai et al., 1991; Holland and Urai, 2010; Fagereng et al., 2010; Bons et al., 2012; Woodcock et al., 2014). Extensional veins oriented perpendicular to stylolites (Fig. 3e, g) are linked to syn-thrusting shortening (Gratier et al., 2013; Smeraglia et al., 2020). The studied veins are therefore interpreted as the product of tectonic fault slip, and their $\mathrm{U}-\mathrm{Pb}$ ages are regarded as representative of faulting activity.

We recognize three regional tectonic phases between the middle Eocene and the Pliocene (Figs. 7 and 8), which are linked to the long-lived tectonic activity of the Alpine foreland evolution. The presented ages should be regarded as minimum ages for the onset of deformation at the studied faults or as maximum ages for its termination. Potentially older or younger deformation phases recorded by other veins and slickenfibres not sampled and analysed here may have been missed. As commonly done in carbonate LAICP-MS U-Pb dating, no disequilibrium correction for initial ${ }^{234} \mathrm{U} /{ }^{238} \mathrm{U}$ and ${ }^{230} \mathrm{Th}$ was applied. This may cause underestimation of young ( $<10 \mathrm{Myr})$ samples (Roberts et al., 2020) 
(a) Montlebon thrust

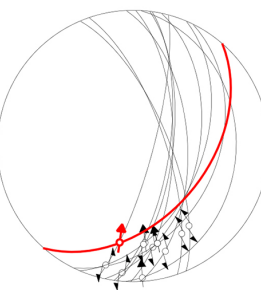

(b) Buron thrust

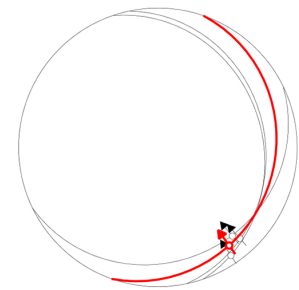

(c) Fuans thrust

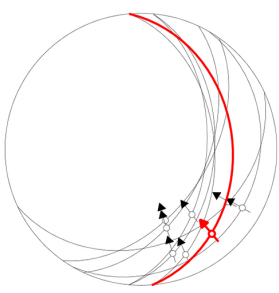

(d) Arguel thrust

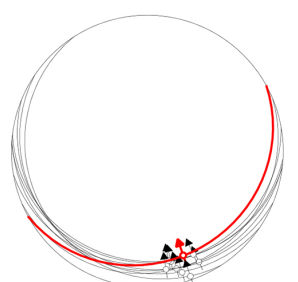

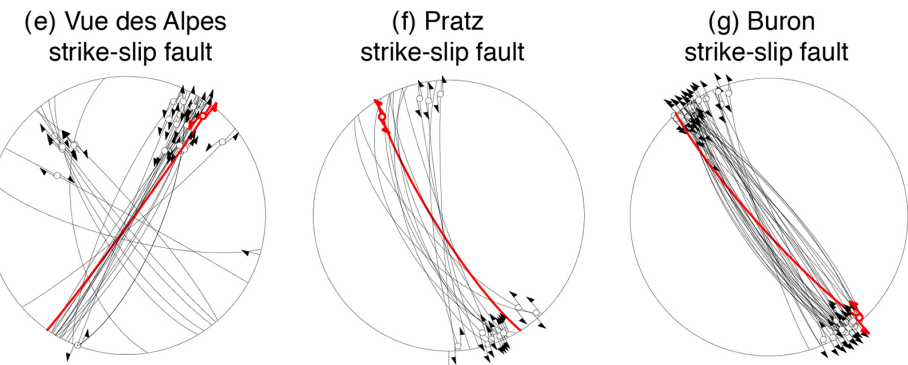

Figure 2. Lower Schmidt hemisphere projection of fault-slip data and slip vectors for thrust and strike-slip faults. Dated faults in red. (a) Montlebon thrust. (b) Buron thrust. (c) Fuans thrust. (d) Arguel thrust. (e) Vue des Alpes strike-slip fault. (f) Pratz strike-slip fault. (g) Buron strike-slip fault.
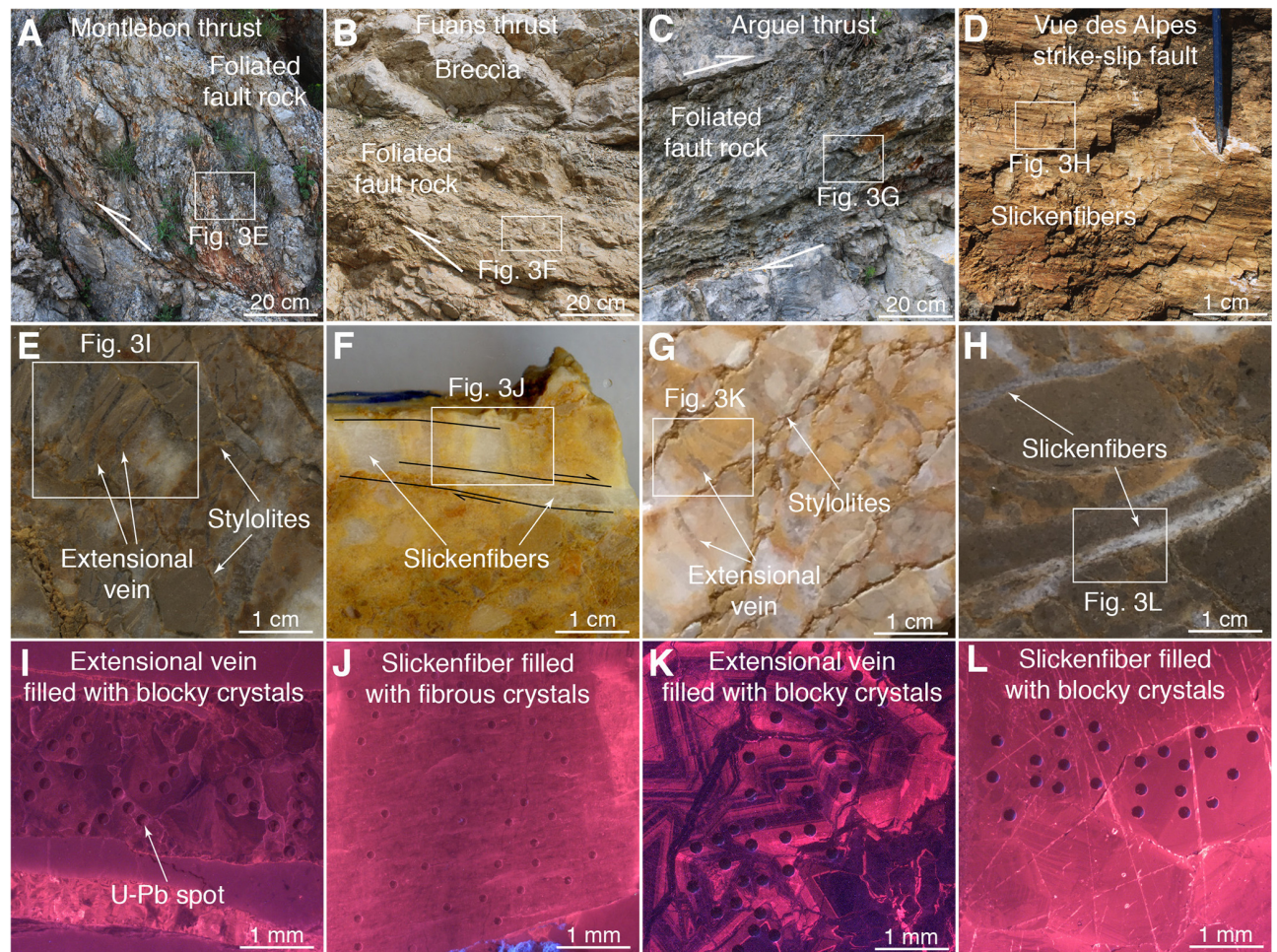

Figure 3. Foliated fault rocks in the fault core of the Montlebon thrust (a), Arguel thrust (b), and (c) Fuans thrust. (d) Detail of minor fault plane along the Vue des Alpes strike-slip fault showing calcite slickenfibres. (e) Hand sample from the Montlebon thrust showing host rock sigmoids bounded by stylolites and extensional veins perpendicular to stylolites. (f) Hand sample from the Fuans thrust showing host rock sigmoids bounded by stylolites and extensional veins perpendicular to stylolites. (g) Hand sample from the Arguel thrust showing extensional veins with crackle-like texture. (h) Hand sample from a minor fault plane along the Vue des Alpes strike-slip fault showing slickenfibres developed along dissolution planes. (i-l) Cathodoluminescence microphotographs of thin sections showing extensional veins and slickenfibres from the studied faults with ablation craters of the $\mathrm{U}-\mathrm{Pb}$ analyses. 

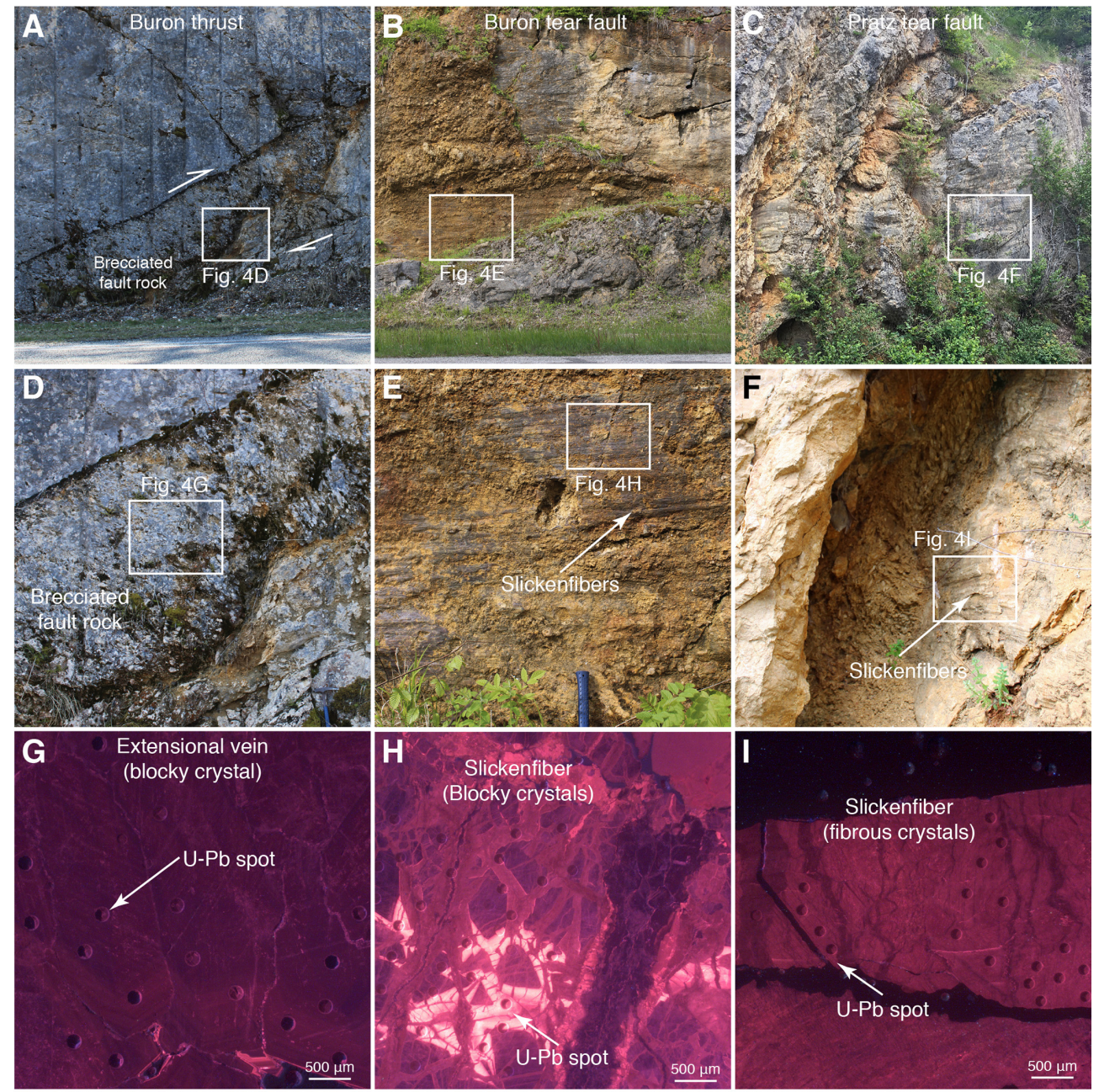

Figure 4. (a) Buron thrust. (b) Buron tear fault. (c) Pratz tear fault. (d) Brecciated fault rocks in the fault core of the Buron thrust. (e) Brecciated fault rocks cut by sharp fault planes in the fault core of the Buron tear fault. (f) Foliated fault rock cut by sharp fault planes in the fault core of the Pratz tear fault. (g-i) Cathodoluminescence microphotographs of thin sections showing extensional veins and slickenfibres from the studied faults with ablation craters of the $\mathrm{U}-\mathrm{Pb}$ analyses.

and accordingly, they should be regarded as reflecting maximal ages.

The U-Pb ages are regionally consistent in terms of the tectonic evolution of the Jura FTB, and the microstructures of the analysed veins and slickenfibres indicate precipitation during syn- to early post-slip fluid influx. However, although $\mathrm{U}-\mathrm{Pb}$ dating was performed on crystals with no indication of later open-system alteration based on CL microscopy, possible late fluid infiltration and calcite recrystallization cannot be excluded as previously suggested by other studies (Beaudoin and Lacombe, 2018; Hoareau et al., 2021; Roberts et al., 2020, 2021).

Sample BUS1 clearly shows multiple calcite phases indicating vein re-opening and potentially different ages (Fig. 4h). However, the Tera-Wasserburg diagram of BUS1 shows a single age trend with a low MSWD of 0.82 (Fig. 6d). This would not be observed in a sample that experienced crystallization at significantly different times. Therefore, sample BUS1 reflects calcite precipitation within a time interval smaller than what would result in multiple age trends.

The oldest tectonic phase is recorded by two horizontal slickenfibres dated to $44.7 \pm 2.6$ and $48.4 \pm 1.5 \mathrm{Ma}$ in Ypresian-Lutetian times (middle Eocene) along the Vue des Alpes strike-slip fault (Fig. 7). These ages are $\sim 10 \mathrm{Myr}$ older than the onset of the extensional tectonic activity in the Priabonian (late Eocene) related to Rhine Graben opening (Sissingh, 1998; Mazurek et al., 2018). The strike-slip faulting in Eocene times is consistent with fault-slip data of Homberg et al. (1997). We propose that the YpresianLutetian tectonic activity can be related to the late MesozoicEocene far-field tectonic shortening in the European plate foreland due to the advancing Alpine orogen (Mazurek et al., 2006; Timar-Geng et al., 2006 Fig. 8a). However, previous studies suggested that middle Eocene strike-slip fault- 


\section{$\mathrm{U}-\mathrm{Pb}$ ages from thrusts}

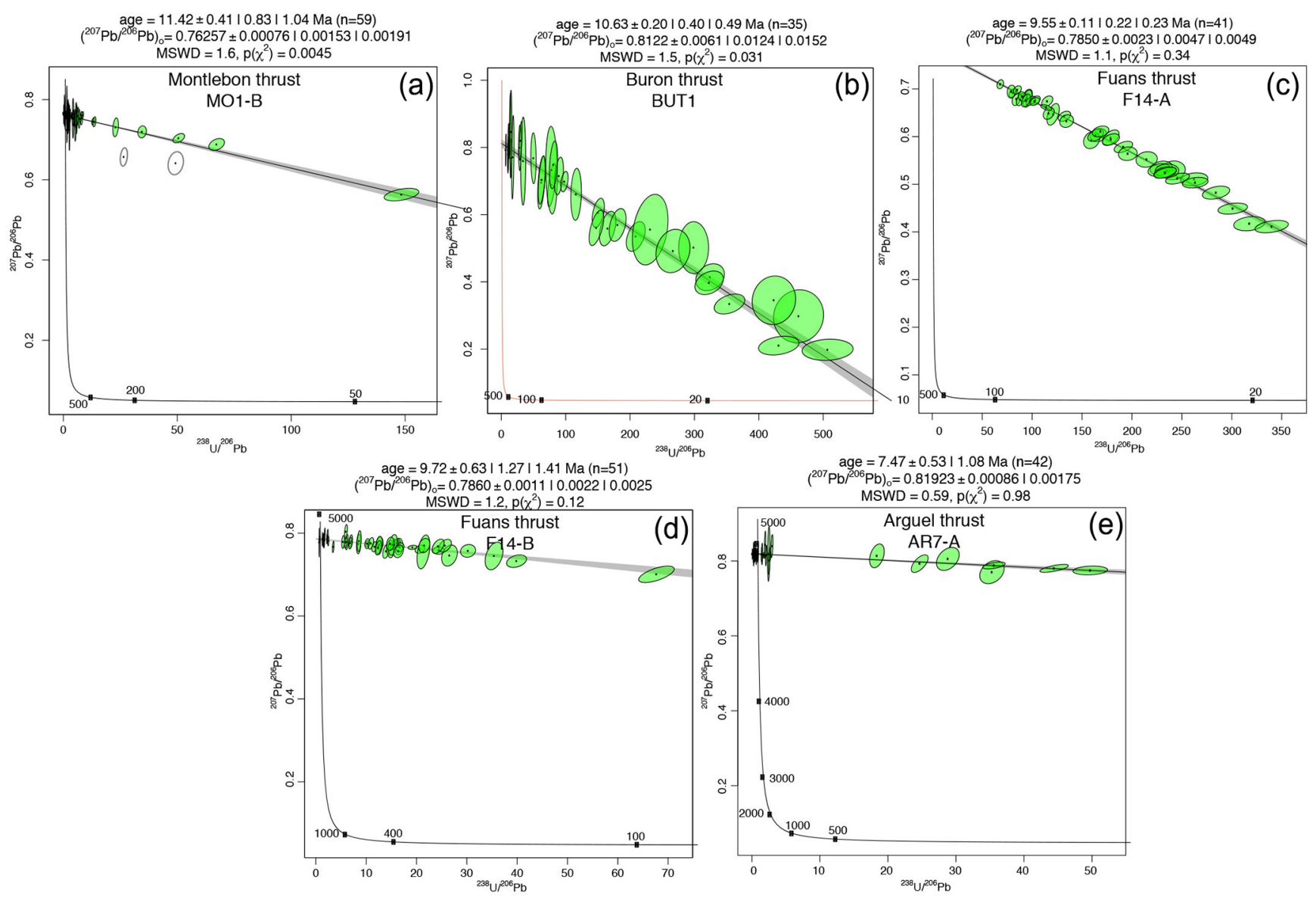

Figure 5. Tera-Wasserburg concordia diagrams of thrust faults. (a) Montlebon thrust. (b) Buron thrust. (c, d) Fuans thrust. (e) Arguel thrust.

ing in the Jura area can be also related to the far-field effect of the Pyrenean compression (Bergerat, 1987; Homberg et al., 2002). The Pyrenean far-field effect is also recognized in the Paris Basin (e.g. Lacombe et al., 1990; Lacombe and Mouthereau, 1999; Lacombe and Obert, 2000), in eastern France (Lacombe et al., 1993), and even in the United Kingdom (Hibsch et al., 1995), where Pyrenean-related calcite veins were dated by $\mathrm{U}-\mathrm{Pb}$ (ages between 55 and $25 \mathrm{Ma}$; Parrish et al., 2018). Therefore, we cannot fully distinguish if the strike-slip fault activity during Ypresian-Lutetian times is related to the Pyrenean or to the Alpine shortening. Further studies are necessary to better constrain the origin of pre-Miocene fault activity in the European foreland.

Structural analyses of the studied thrusts highlight N- to NW-oriented tectonic transport directions (Fig. 4a-d) consistent with the regional NW-SE to N-S compressional phase that has affected the Jura fold and thrust belt since the Miocene (Philippe et al., 1996; Becker, 2000; Homberg et al., 2002; Ustaszewski and Schmid, 2006; Madritsch et al., 2008; Looser et al., 2021). Although age uncertainties do not allow a distinction beyond doubt and the limited numbers of $\mathrm{U}-\mathrm{Pb}$ ages and studied thrusts provide a limited picture, the Jura imbrication seems to have occurred by in-sequence thrusting. The oldest observed thrust ages are SerravallianMessinian and become progressively younger moving from the inner (SE) toward the external (NW) part: from 11.4 \pm 1.1 , $10.6 \pm 0.5,9.7 \pm 1.4$, and $9.6 \pm 0.3 \mathrm{Ma}$ on the same thrust and $7.5 \pm 1.1 \mathrm{Ma}$ in the Montlebon, Buron, Fuans, and $\mathrm{Ar}-$ guel thrusts (Figs. 7 and 8b). These ages are consistent with the time interval of $\sim 14.5-3.3 \mathrm{Myr}$ suggested for thrusting activity from biostratigraphic dating of syn- to post-tectonic sediments (Becker, 2000, and references therein) and from calcite $\mathrm{U}-\mathrm{Pb}$ ages of thrust activity in the eastern Jura FTB (Looser et al., 2021; Fig. 7).

Previous studies interpreted the subvertical strike-slip faults in the Jura FTB as tear faults, with activity during thrusting and folding (Sommaruga, 1997; Looser et al., 2021). Our structural analyses and $\mathrm{U}-\mathrm{Pb}$ ages from the studied strike-slip faults support this interpretation. In particular, strike-slip faults are subvertical and are roughly parallel 


\section{$\mathrm{U}-\mathrm{Pb}$ ages from strike-slip faults}
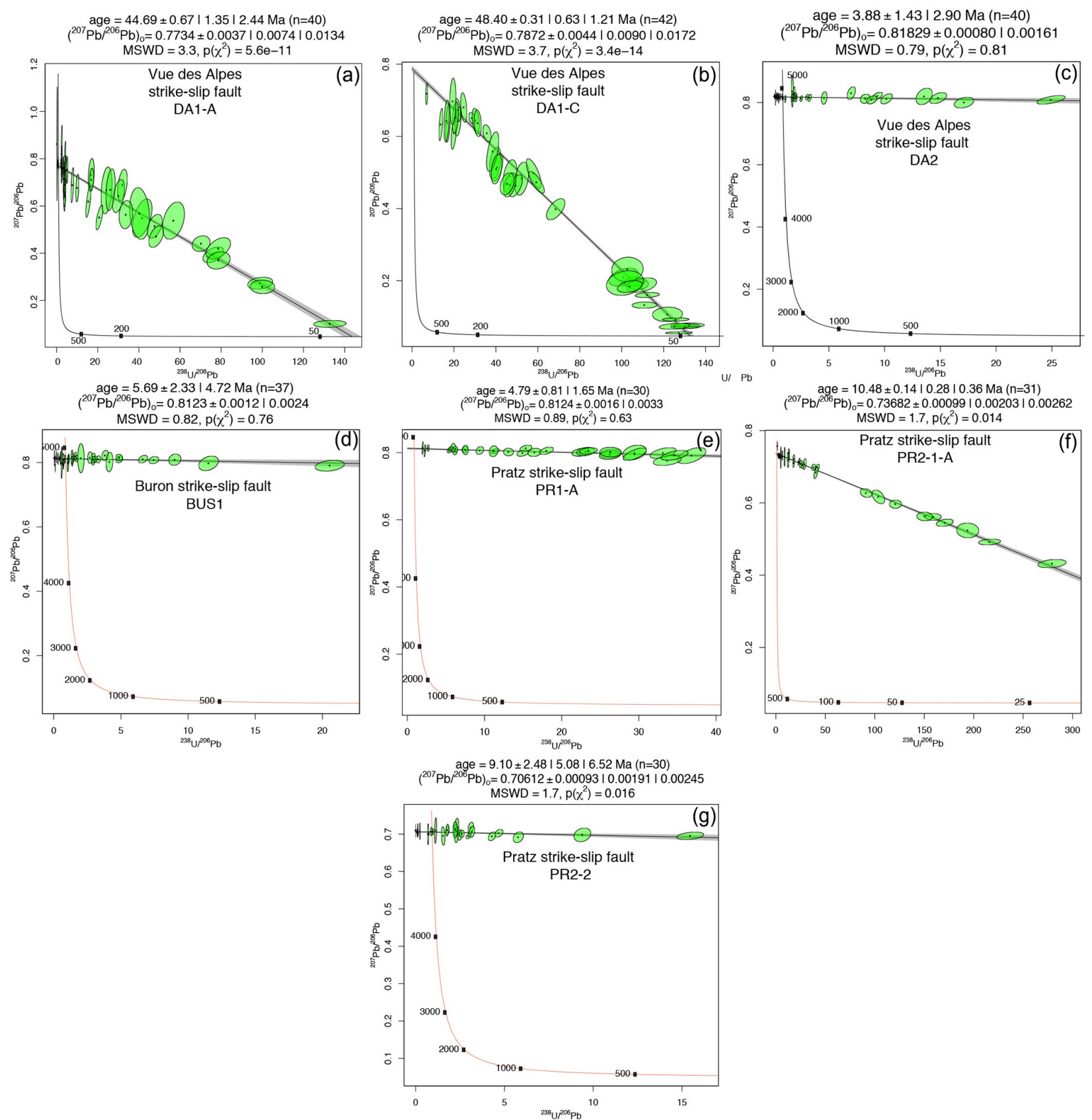

Figure 6. Tera-Wasserburg concordia diagrams of strike-slip faults. (a-c) Vue des Alpes strike-slip fault. (d) Buron strike-slip fault. (e-g) Pratz strike-slip fault.

or oblique to the regional transport directions inferred from thrust kinematics (compare tectonic transport directions of Fig. 4a-d with those of Fig. 4f, g), a common feature of tear faults developed during thrusting (Twiss and Moores, 1992).

The Buron thrust, active at $10.6 \pm 0.5 \mathrm{Ma}$, was cross-cut by the Buron tear fault $\sim 5 \mathrm{Myr}$ later, at $5.7 \pm 4.7 \mathrm{Ma}$ (Figs. 7 and $8 \mathrm{c}$ ). The Pratz tear fault was active at $10.5 \pm 0.4 \mathrm{Ma}$ and
$9.1 \pm 6.5 \mathrm{Ma}$, indicating tear faulting generation during coeval thrust propagation, and further late-orogenic reactivation at $4.8 \pm 1.7 \mathrm{Ma}$ (Figs. 7 and $8 \mathrm{~b}$ ). These data indicate that tear faulting occurred during syn- to late-orogenic times (Fig. 8b, c). In addition, a late-orogenic phase is recorded by an extensional vein from the Vue des Alpes strike-slip fault showing a Pliocene age of $3.9 \pm 2.9 \mathrm{Ma}$ (Fig. 7). This age 


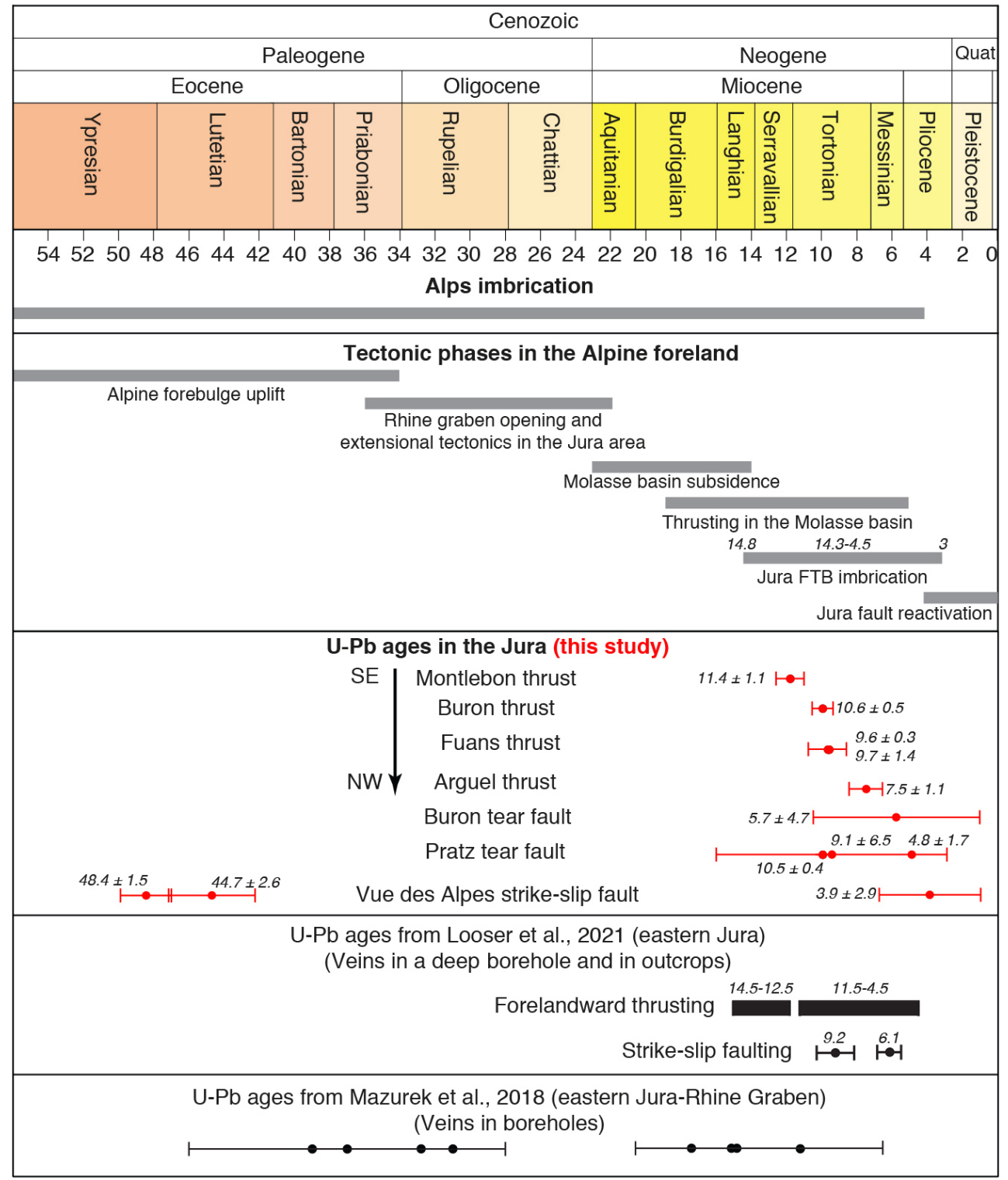

Figure 7. Main tectonic phases in the Alps and in the Alpine foreland. Age constraints shown as grey bars are from Burkhard and Sommaruga (1998), Ustaszewski et al. (2006), Madritsch et al. (2008), Bellahsen et al. (2014), and Von Hagke et al. (2014). For calcite U-Pb data, all uncertainties are represented as $2 \sigma$.

has been measured on an extensional vein that cannot be directly related to fault slip. Therefore, we cannot completely exclude that this age represents a late alteration event not directly linked to fault slip during the Pliocene. However, the $3.9 \pm 2.9 \mathrm{Ma}$ age is consistent with late-orogenic deformation between 4.2 and $2.9 \mathrm{Ma}$ documented in the frontal part of the Jura FTB (Madritsch et al., 2008, and references therein). The 3.9 $\pm 2.9 \mathrm{Ma}$ age from the Vue des Alpes strike-slip fault is $\sim 40$ Myr younger than the middle Eocene ages (44.7 \pm 2.6 and $48.4 \pm 1.5 \mathrm{Ma}$ ) measured on the same fault, suggesting the reactivation of the Vue des Alpes strike-slip fault during late Jura shortening. This inference is also consistent with field cross-cutting relationships indicating reactivation of pre-existing strike-slip faults as tear faults (Homberg et al., 1997).

We regard the retrieved age as fault reactivation of the Vue des Alpes strike-slip fault and relate it to a stress change from pure compression to a strike-slip state of stress coupled with the occurrence of an inherited strike-slip fault favourably oriented with respect to the regional stress field. This stress change associated with tear fault development can be related to progressive fold-and-thrust belt thickening during the latest stage of Jura imbrication, which led to an increase in the principal vertical stress (sigma 3 ) and a switch between 


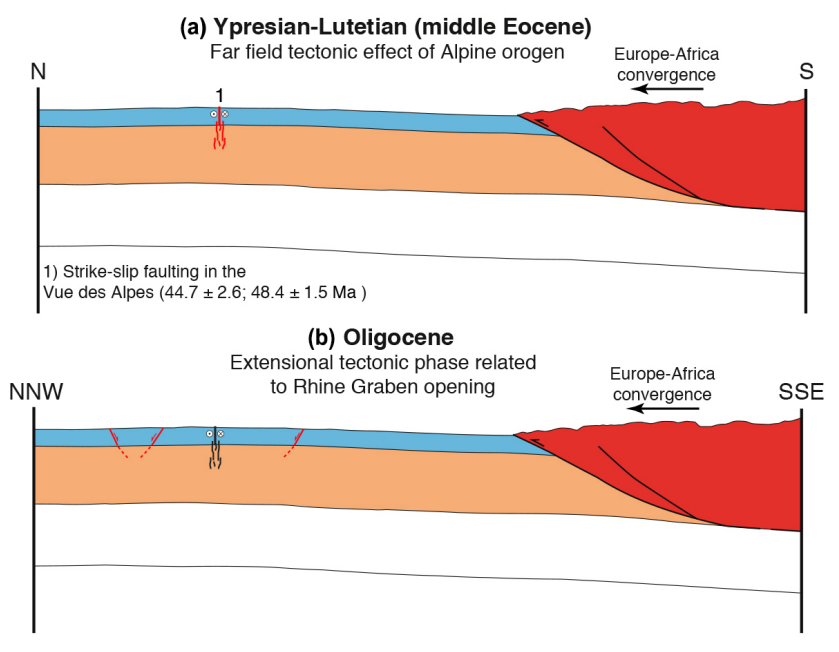

(c) Serravallian-Messinian (middle-late Miocene)

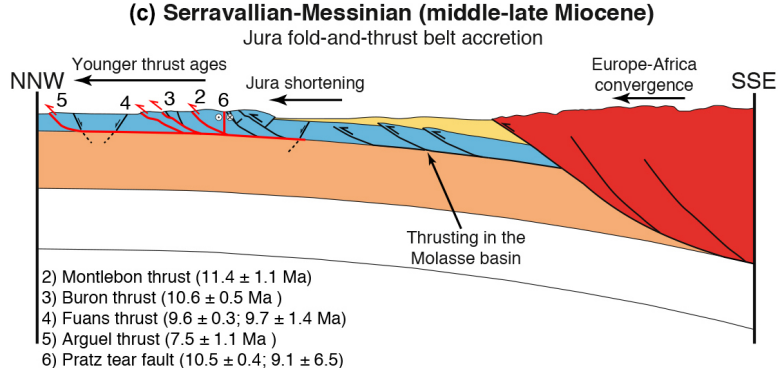

5) Arguel thrust $(7.5 \pm 1.1 \mathrm{Ma})$

(d) late Miocene-middle Pliocene

Tear fault reactivation in the Jura fold-and-thrust belt

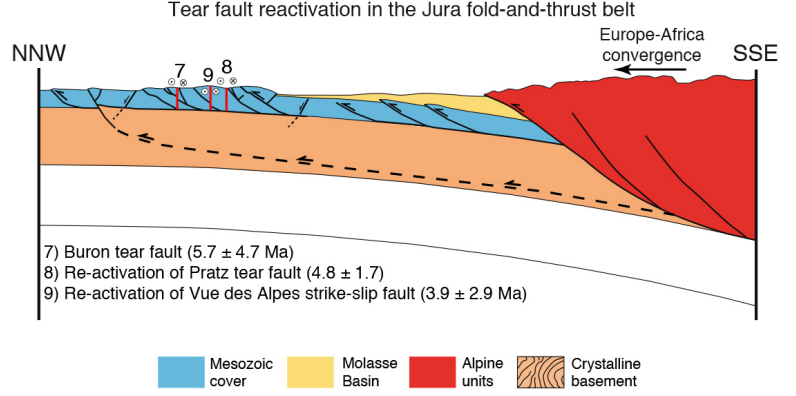

Figure 8. (a-d) Schematic reconstruction of the main tectonic phases dated in the Jura area in the regional context of the Alpine foreland system evolution.

sigma 3 and sigma 2 (Ferril et al., 2021). Shortening is still active in the Jura FTB and tear faults (also reactivated tear faults) are seismogenic (Thouvenot et al., 1998).

The presented tectonic reconstruction depicts a stable evolution of the Jura FTB wedge by possible in-sequence thrusting consistent with thrust imbrication above the low-friction decollement consisting of evaporites (Fig. 8a-c). By contrast, out-of-sequence thrusting occurred as late as Messinianearly Pliocene times in the proximal Molasse Basin (Von Hagke et al., 2012, 2014) and in the Alps (Bellahsen et al., 2014). This tectonic framework suggests a stable topographic evolution of the critical taper and of the topographic profile in the Jura FTB. Finally, this study constrains a longlived polyphase tectonic history of the northwestern Alpine foreland system along the convergent boundary between the European and African plates from the middle Eocene to the Pliocene.

Data availability. Data have been stored within the EarthChem repository: https://doi.org/10.26022/IEDA/112155 (Smeraglia et al., 2021).

Supplement. The supplement related to this article is available online at: https://doi.org/10.5194/se-12-2539-2021-supplement.

Author contributions. LS was responsible for investigation, data curation, formal analysis, visualization, writing the original draft, and funding acquisition. NL was responsible for investigation, data curation, formal analysis, visualization, and writing the original draft. OF was responsible for validation, investigation, data curation, writing (review and editing), and funding acquisition. FC was responsible for validation, investigation, data curation, writing (review and editing), and funding acquisition. MG was responsible for investigation, data curation, and formal analysis. SB was responsible for validation, data curation, formal analysis, investigation, writing (review and editing), and funding acquisition.

Competing interests. The contact author has declared that neither they nor their co-authors have any competing interests.

Disclaimer. Publisher's note: Copernicus Publications remains neutral with regard to jurisdictional claims in published maps and institutional affiliations.

Acknowledgements. We thank CASP (https://www.casp.org.uk/, last access: 7 October 2021) for financial support during fieldwork activity by the Andy Whitham Fieldwork Award 2019 to Luca Smeraglia. Financial support by Borsa di Perfezionamento Estero 2017 (Sapienza) to Luca Smeraglia, UMR 6249, and OSU Theta projects to Olivier Fabbri and Flavien Choulet are acknowledged. $\mathrm{U}-\mathrm{Pb}$ analyses were funded by the Swiss National Science Foundation project number 200021_169849 to Stefano M. Bernasconi. We thank Jon Mosar, Marc Schori, Anna Sommaruga, Catherine Mottram, Leoni Weiss, and Christoph Von Hagke for constructive discussions and suggestions, also during fieldwork. We thank the editors Susanne Buiter and Florian Fusseis and two reviewers Olivier Lacombe and Nick Roberts for their constructive comments, which helped to improve the paper.

Financial support. This research has been supported by the Schweizerischer Nationalfonds zur Förderung der Wissenschaftlichen Forschung (grant no. 200021_169849), the Sapienza Università di Roma (Borsa di Perfezionamento Estero 2017 grant), and CASP (Andy Whitham Fieldwork Award). 
Review statement. This paper was edited by Florian Fusseis and reviewed by Olivier Lacombe and Nick Roberts.

\section{References}

Affolter, T. and Gratier, J. P.: Map view retrodeformation of an arcuate fold-and-thrust belt: The Jura case, J. Geophy. Res.-Sol. Ea., 109, B03404, https://doi.org/10.1029/2002JB002270, 2004.

Beaudoin, N. and Lacombe, O.: Recent and future trends in paleopiezometry in the diagenetic domain: Insights into the tectonic paleostress and burial depth history of fold-and-thrust belts and sedimentary basins, J. Struct. Geol., 114, 357-365, 2018.

Beaudoin, N., Lacombe, O., Roberts, N. M., and Koehn, D.: U-Pb dating of calcite veins reveals complex stress evolution and thrust sequence in the Bighorn Basin, Wyoming, USA, Geology, 46, 1015-1018, 2018.

Becker, A.: The Jura Mountains - an active foreland fold-and-thrust belt?, Tectonophysics, 321, 381-406, 2000.

Bellahsen, N., Mouthereau, F., Boutoux, A., Bellanger, M., Lacombe, O., Jolivet, L., and Rolland, Y.: Collision kinematics in the western external Alps, Tectonics, 33, 1055-1088, 2014.

Bergerat, F.: Stress fields in the European platform at the time of Africa-Eurasia collision, Tectonics 6, 99-132, 1987.

Bons, P. D., Elburg, M. A., and Gomez-Rivas, E.: A review of the formation of tectonic veins and their microstructures, J. Struct. Geol., 43, 33-62, 2012.

Carminati, E., Aldega, L., Smeraglia, L., Scharf, A., Mattern, F., Albert, R., and Gerdes, A.: Tectonic evolution of the Northern Oman Mountains, part of the Strait of Hormuz Syntaxis: new structural and paleothermal analyses and U-Pb dating of synkinematic calcite, Tectonics, 39, e2019TC005936, https://doi.org/10.1029/2019TC005936, 2020.

Craig, M. S. and Warvakai, K.: Structure of an active foreland fold and thrust belt, Papua New Guinea, Aust. J. Earth Sci., 56, 719 738, 2009

Fagereng, A., Remitti, F., and Sibson, R. H.: Shear veins observed within anisotropic fabric at high angles to the maximum compressive stress, Nat. Geosci., 3, 482-485, https://doi.org/10.1038/NGEO898, 2010.

Ferril, D. A., Smart, K. J., Cawood, A. J., and Morris, A. P.: The fold-thrust belt stress cycle: Superposition of normal, strike-slip, and thrust faulting deformation regimes, J. Struct. Geol., 148, 482-485, 2021.

Goodfellow, B. W., Viola, G., Bingen, B., Nuriel, P., and KylanderClark, A. R.: Paleocene faulting in SE Sweden from U-Pb dating of slickenfiber calcite, Terra Nova, 29, 321-328, 2017.

Gratier, J. P. and Gamond, J. F.: Transition between seismic and aseismic deformation in the upper crust. London, Geol. Soc. Spec. Publ., 54, 461-473, 1990.

Gratier, J. P., Thouvenot, F., Jenatton, L., Tourette, A., Doan, M. L., and Renard, F.: Geological control of the partitioning between seismic and aseismic sliding behaviours in active faults: evidence from the Western Alps, France, Tectonophysics, 600, 226-242, 2013.

Gruber, M.: Structural Investigations of the Western Swiss Molasse Basin - From 2D Seismic Interpretation to a 3D Geological Model, GeoFocus, 41, 190 pp., 2017.
Guillong, M., Wotzlaw, J.-F., Looser, N., and Laurent, O.: Evaluating the reliability of $\mathrm{U}-\mathrm{Pb}$ laser ablation inductively coupled plasma mass spectrometry (LA-ICP-MS) carbonate geochronology: matrix issues and a potential calcite validation reference material, Geochronology, 2, 155-167, https://doi.org/10.5194/gchron-2-155-2020, 2020.

Hansman, R. J., Albert, R., Gerdes, A., and Ring, U.: Absolute ages of multiple generations of brittle structures by $\mathrm{U}-\mathrm{Pb}$ dating of calcite, Geology, 46, 207-210, 2018.

Hibsch, C., Jarrige, J. J., Cushing, E. M., and Mercier, J.: Palaeostress analysis, a contribution to the understanding of basin tectonics and geodynamic evolution. Example of the Permian/Cenozoic tectonics of Great Britain and geodynamic implications in western Europe, Tectonophysics, 252, 103-136, 1995.

Hoareau, G., Crognier, N., Lacroix, B., Aubourg, C., Roberts, N. M., Niemi, N., Branellec, M., Beaudoin, N., and Suarez Ruiz, I.: Combination of $\Delta 47$ and $\mathrm{U}-\mathrm{Pb}$ dating in tectonic calcite veins unravel the last pulses related to the Pyrenean Shortening (Spain), Earth Planet. Sc. Lett., 553, 116636, https://doi.org/10.1016/j.epsl.2020.116636, 2021.

Holland, M. and Urai, J. L.: Evolution of anastomosing crack-seal vein networks in limestones: Insight from an exhumed highpressure cell, Jabal Shams, Oman Mountains, J. Struct. Geol., 32, 1279-1290, 2010.

Homberg, C., Hu, J. C., Angelier, J., Bergerat, F., and Lacombe, O.: Characterization of stress perturbations near major fault zones: insights from 2-D distinct-element numerical modelling and field studies (Jura mountains), J. Struct. Geol., 19, 703-718, 1997.

Homberg, C., Bergerat, F., Philippe, Y., Lacombe, O., and Angelier, J.: Structural inheritance and Cenozoic stress fields in the Jura fold-and-thrust belt (France), Tectonophysics, 357, 137158, 2002.

Jordan, P.: Evidence for large-scale decoupling in the Triassic evaporites of Northern Switzerland: an overview, Eclogae Geol. Helv., 85, 677-693, 1992.

Lacombe, O. and Bellahsen, N.: Thick-skinned tectonics and basement-involved fold-thrust belts: insights from selected Cenozoic orogens, Geol. Mag., 153, 763-810, 2016.

Lacombe, O. and Mouthereau, F.: What is the real front of orogens? The Pyrenean orogen as a case study, Comptes Rendus de 1'Academie des Sciences Series IIA Earth and Planetary Science, 329, 889-896, 1999.

Lacombe, O. and Mouthereau, F.: Basement-involved shortening and deep detachment tectonics in forelands of orogens: Insights from recent collision belts (Taiwan, Western Alps, Pyrenees), Tectonics, 21, 1-22, https://doi.org/10.1029/2001TC901018, 2002.

Lacombe, O. and Obert, D.: Structural inheritance and cover deformation: Tertiary folding and faulting in, the western Paris Basin, Comptes rendus de l'academie des sciences serie ii fascicule asciences de la terre et des planetes, 330, 793-798, 2000.

Lacombe, O., Angelier, J., Laurent, P., Bergerat, F., and Tourneret, C.: Joint analyses of calcite twins and fault slips as a key for deciphering polyphase tectonics: Burgundy as a case study, Tectonophysics, 182, 279-300, 1990.

Lacombe, O., Angelier, J., Byrne, D., and Dupin, J. M.: EoceneOligocene tectonics and kinematics of the Rhine-Saone continental transform zone (eastern France), Tectonics, 12, 874-888, 1993. 
Lacombe, O., Lavé, J., Roure, F. M., and Vergés, J. (Eds.).: Thrust belts and foreland basins: From fold kinematics to hydrocarbon systems, Springer Science and Business Media, Berlin, ISBN 978-3-540-69426-7, 2007.

Looser, N., Madritsch, H., Guillong, M., Laurent, O., Wohlwend, S., and Bernasconi, S. M.: Absolute age and temperature constraints on deformation along the basal deìcollement of the Jura fold-and- thrust belt from carbonate $\mathrm{U}-\mathrm{Pb}$ dating and clumped isotopes, Tectonics, 40, e2020TC006439, https://doi.org/10.1029/2020TC006439, 2021.

Madritsch, H., Schmid, S. M., and Fabbri, O.: Interactions between thin- and thick-skinned tectonics at the northwestern front of the Jura fold-and-thrust belt (eastern France), Tectonics, 27, 1-31, 2008.

Mazurek, M., Hurford, A. J., and Leu, W.: Unravelling the multistage burial history of the Swiss Molasse Basin: integration of apatite fission track, vitrinite reflectance and biomarker isomerisation analysis, Basin Research, 18, 27-50, 2006.

Mazurek, M., Davis, D. W., Madritsch, H., Rufer, D., Villa, I., Sutcliffe, C. N., de Haller, A., and Traber, D.: Veins in clayrich aquitards as records of deformation and fluid-flow events in northern Switzerland, Appl. Geochem., 95, 57-70, 2018.

Merle, O. and Michon, L.: The formation of the West European Rift; a new model as exemplified by the Massif Central area, B. Soc. Geol. Fr., 172, 213-221, 2001.

Mosar, J.: Present-day and future tectonic underplating in the western Swiss Alps: reconciliation of basement/wrench-faulting and décollement folding of the Jura and Molasse basin in the Alpine foreland, Earth Planet. Sc. Lett., 173, 143-155, 1999.

Nuriel, P., Weinberger, R., Kylander-Clark, A. R. C., Hacker, B. R., and Craddock, J. P.: The onset of the Dead Sea transform based on calcite age-strain analyses, Geology, 45, 587-590, 2017.

Parrish, R. R., Parrish, C. M., and Lasalle, S.: Vein calcite dating reveals Pyrenean orogen as cause of Paleogene deformation in southern England, J. Geol. Soc., 175, 425-442, 2018.

Pfiffner, O. A.: Geology of the Alps, Chichester, John Wiley and Son, ISBN 978-1-118-70812-5, Hoboken, New Jersey, USA, 2014.

Philippe, Y., Colletta, B., Deville, E., and Mascle, A.: The Jura foldand-thrust belt: a kinematic model based on map-balancing, Mémoires du Muséum national d'histoire naturelle, 170, 235-261, 1996.

Radaideh, O. M. and Mosar, J.: Cenozoic Tectonic Deformation Along the Pontarlier Strike-Slip Fault Zone (Swiss and French Jura Fold-and-Thrust Belt): Insights From Paleostress and Geomorphic Analyses, Tectonics, 40, e2021TC006758, https://doi.org/10.1029/2021TC006758, 2021.

Rime, V., Sommaruga, A., Schori, M., and Mosar, J.: Tectonics of the Neuchâtel Jura Mountains: insights from mapping and forward modelling, Swiss J. Geosci., 112, 563-578, 2019.

Roberts, N. M., Drost, K., Horstwood, M. S., Condon, D. J., Chew, D., Drake, H., and Haslam, R.: Laser ablation inductively coupled plasma mass spectrometry (LA-ICP-MS) U-Pb carbonate geochronology: strategies, progress, and limitations, Geochronology, 2, 33-61, 2020.

Roberts, N. M., Žák, J., Vacek, F., and Sláma, J.: No more blind dates with calcite: Fluid-flow vs. fault-slip along the Očkov thrust, Prague Basin. Geosci. Front., 12, 101143, https://doi.org/10.1016/j.gsf.2021.101143, 2021.
Sissingh, W.: Comparative Tertiary stratigraphy of the Rhine Graben, Bresse Graben and Molasse Basin: correlation of Alpine foreland events, Tectonophysics, 1-4, 300, 249-284, https://doi.org/10.1016/S0040-1951(98)00243-1, 1998.

Smeraglia, L., Aldega, L., Billi, A., Carminati, E., Di Fiore, F., Gerdes, A., and Vignaroli, G.: Development of an Intrawedge Tectonic Mélange by Out-of-Sequence Thrusting, Buttressing, and Intraformational Rheological Contrast, Mt. Massico Ridge, Apennines, Italy, Tectonics, 38, 1223-1249, 2019.

Smeraglia, L., Fabbri, O., Choulet, F., Buatier, M., Boulvais, P., Bernasconi, S. M., and Castorina, F.: Syntectonic fluid flow and deformation mechanisms within the frontal thrust of foreland fold-and-thrust belt: Example from the Internal Jura, Eastern France, Tectonophysics, 778, 228178, https://doi.org/10.1016/j.tecto.2019.228178, 2020.

Smeraglia, L., Looser, N., Fabbri, O., Choulet, F., Guillong, M., and Bernasconi, S. M.: Dataset for "U-Pb dating of middle EocenePliocene multiple tectonic pulses in the Alpine foreland" by Smeraglia et al., Version 1.0, Interdisciplinary Earth Data Alliance (IEDA) [data set], https://doi.org/10.26022/IEDA/112155, 2021.

Sommaruga, A.: Geology of the Central Jura and the Molasse basin: New insight into an evaporite-based foreland fold and thrust belt, Mémoires de la Société Neuchâteloise de Sciences Naturelles, 12, 176 pp., 1997.

Sommaruga, A., Mosar, J., Schori, M., and Gruber, M.: The role of the Triassic evaporites underneath the North Alpine foreland, in: Permo- Triassic salt provinces of Europe, North Africa and the Atlantic Margins: tectonics and hydrocarbon potential, chapter 22 (IV), edited by: Soto, J., Flinch, J., and Tari, G., Elsevier, Amsterdam, the Netherlands, 2017.

Thouvenot, F., Fréchet, J., Tapponnier, P., Thomas, J. C., Le Brun, B., Ménard, G., and Paul, A.: The ML 5.3 Epagny (French Alps) earthquake of 1996 July 15: a long-awaited event on the Vuache Fault, Geophys. J. Int., 135, 876-892, 1998.

Timar-Geng, Z., Fügenschuh, B., Wetzel, A., and Dresmann, H.: The low termperature thermal history of northern Switzerland as revealed by fission track analysis and inverse thermal modelling, Eclogae Geol. Helv., 99, 255-270, 2006.

Twiss, R. J. and Moores, E. M.: Structural geology, Freeman and Co., San Francisco, pp. 532, ISBN 071672252 6, 1992.

Urai, J. L., Williams, P. F., and Van Roermund, H. L. M.: Kinematics of crystal growth in syntectonic fibrous veins, J. Struct. Geol., $13,823-836,1991$.

Ustaszewski, K. and Schmid, S. M.: Control of preexisting faults on geometry and kinematics in the northernmost part of the Jura fold-and-thrust belt, Tectonics, 25, 1-26, https://doi.org/10.1029/2005TC001915, 2006.

Ustaszewski, K. and Schmid, S. M.: Latest Pliocene to recent thickskinned tectonics at the Upper Rhine Graben-Jura Mountains junction, Sw. J. Geosci., 100, 293-312, 2007.

Van der Pluijm, B. A., Hall, C. M., Vrolijk, P. J., Pevear, D. R., and Covey, M. C.: The dating of shallow faults in the Earth's crust, Nature, 412, 172-175, 2001.

Vergés, J., Muñoz, J. A., and Martínez, A.: South Pyrenean fold and thrust belt: The role of foreland evaporitic levels in thrust geometry, in: Thrust tectonics, Springer, Dordrecht, 255-264, 1992.

Von Hagke, C., Cederbom, C. E., Oncken, O., Stöckli, D. F., Rahn, M. K., and Schlunegger, F.: Linking the northern Alps with 
their foreland: The latest exhumation history resolved by lowtemperature thermochronology, Tectonics, 31, TC5010, 1-25, https://doi.org/10.1029/2011TC003078, 2012.

Von Hagke, C., Oncken, O., Ortner, H., Cederbom, C. E., and Aichholzer, S.: Late Miocene to present deformation and erosion of the Central Alps - Evidence for steady state mountain building from thermokinematic data, Tectonophysics, 632, 250-260, 2014.
Vrolijk, P., Pevear, D., Covey, M., and LaRiviere, A.: Fault gouge dating: history and evolution, Clay Miner., 53, 305-324, 2018.

Woodcock, N. H., Miller, A. V. M., and Woodhouse, C. D.: Chaotic breccia zones on the Pembroke Peninsula, south Wales: Evidence for collapse into voids along dilational faults, J. Struct. Geol., 69, 91-107, 2014. 